\title{
ПОЛИТИЧЕСКИЕ РАССЛЕДОВАНИЯ В ИНТЕРНЕТ-ПРОЕКТАХ НОВОГО ТИПА ${ }^{1}$
}

\author{
Валерия Игоревна Забиранко \\ Московский гуманитарный университет
}

\begin{abstract}
Аннотация: 2018-2020 г2. отмечень ростом числа политических расследований в интернете и появлением новых расследовательских интернет-проектов. Это свидетельствует как о возросшем спросе аудитории на качественную расследовательскую журналистику, так $и$ о том, что традиционные СМИ этот запрос удовлетворяют. В данной статье представлен обзор и выделены специфические черты наиболее значимых русскоязычных интернет-проектов, спещиализирующихся на политических расследованиях: «Важные истории», «Проект», «Ваzа», «The Insider».
\end{abstract}

Ключевые слова: интернет-проект, медиа, новости, интервью, видео-хостинг, традиичонные СМИ, телевидение, печать, сетевые ресурсы

\section{POLITICAL INVESTIGATIONS IN THE INTERNET-PROJECTS OF A NEW TYPE}

\author{
Valeria Igorevna Zabiranko \\ Moscow University for the Humanities
}

\begin{abstract}
Internet and the emergence of new investigative Internet projects. This indicates both the increased demand of the audience for high-quality investigative journalism, and the fact that the traditional media satisfy this request. This article provides an overview and highlights the specific features of the most significant Russian-language Internet projects specializing in political investigations: "Important stories», "Project», «Baza», «The Insider».
\end{abstract}

Keywords: Internet project, media, news, interviews, video hosting, traditional media, television, print, network resources

«Проект» - новое российское медиа, запущенное в 2018 г. бывшим главным редактором телеканала «Дождь» Романом Баданиным. По словам Баданина, «Проект» занимается сложными журналистскими жанрами: расследованиями, репортажами, историями (Болецкая, 2018). В отличии от аналогичных публикаций в традиционных СМИ, материалы «Проекта» базируются на большом количестве собранных данных. Медиа является некоммерческим и, по словам основателя, существует на деньги спонсоров. В «Проекте» работает около 10 человек, его бюджет - до \$0,5 млн. Периодичности выхода расследований у этого медиа нет, на декабрь 2020 г. на сайте опубликовано более 100 материалов. Одна из публикаций «Проекта» посвящена лидеру Либерально-демократической партии Владимиру Жириновскому (Лукьянова, Рубин и др., 2019). За много лет существования пар-

${ }^{1}$ Статья подготовлена в рамках гранта Президента Российской Федерации для государственной поддержки молодых российских ученых по теме «Социальные сети и мессенджеры: расширение медийной среды» (МК-844.2020.6.). 
тии бессменному главе удалось превратить ее в бизнес-предприятие, которое за деньги из госбюджета, по данным журналистов, реализует коррупционные схемы. Неприкосновенность партии обеспечивается ее лояльностью действующей власти. В расследовании присутствуют фотографии из личных архивов депутата и его семьи. Расследовательский нарратив строится с опорой на интервью, наблюдения, государственные документы (выписки из Росреестра, выписки из документов в Испании и т.д.). Также все расследования в заголовке дополняются иллюстрациями-карикатурами.

В апреле 2020 г. в интернете появилось независимое расследовательское медиа «Важные истории». В команду издания вошли журналисты из «Новой газеты» и Центра по исследованию коррупции и организованной преступности. Новое сетевое издание является некоммерческой организацией и существует на пожертвования. Журналисты начали с расследований, связанных с работой российской системы здравоохранения, выбор был обусловлен пандемией коронавируса. На декабрь 2020 г. на сайте опубликовано около 40 расследований и 20 репортажей. Одним из материалов является расследование от 26 апреля 2020 г. под названием ««Номиналы» закупок» (Анин, Махровская, Шмагун, 2020), в нем журналисты рассказывают о том, как главными поставщиками отечественных аппаратов ИВЛ стали фирмыоднодневки, оформленные на подставных людей. Этими людьми оказались студенты, рабочие со стройки, пропавшие без вести. Все эти фирмы продают аппараты с колоссальной наценкой и связаны с Уральским приборостроительным заводом, который входит в государственную компанию Ростех. В расследовании журналисты используют метод интервью (поговорили с подставными лицами компаний-однодневок, продавцом медоборудования), анализ документов (решения суда разных областей об отмене закупок ИВЛ, выписки из сайта госзакупок, некоторая информация бралась из открытых источников). Интересной особенностью является режим «фактчек» который может включить читатель и увидеть гиперссылки, если ему необходимо более детально ознакомиться с доказательствами.

Медиапроект «Baza» специализируется на эксклюзивных новостях (они выходят в его Telegram-канале) и расследованиях, которые публикуются на отдельных, создаваемых под каждый лонгрид платформах, и в YouTube. Издание было основано бывшими сотрудниками «Life» и «Mash», первой резонансной публикацией было расследование о взрыве жилого дома в Магнитогорске. Трагедия произошла 31 декабря 2018 г. и унесла жизни 39 человек. Авторы расследования доказывают, что разрушение дома произошло в результате теракта. Данную версию до сих пор опровергают власти, а следствие не комментирует представленные журналистами факты. Основной из использованных журналистами методов - интервью (с очевидцами, понятыми, жильцами дома, риелтором, местным дворником, главой газовой службы, бывшими жёнами террористов и т.д.). Также анализировались документы 
(сводки и ориентировки МВД, отчеты газовой компании, видеоматериалы очевидцев, фотографии очевидцев), использовалась скрытая съёмка, запись разговоров, скрытое наблюдение (съём квартиры у риелтора).

В основном издание занимается расследованиями, которые входят в юрисдикцию следственных органов, новостные материалы издания также связаны с убийствами, терактами и т.д. Можно предположить, что информаторами журналистов являются сотрудники следственных органов разных уровней.

Обзор контента расследовательских медиапроектов позволяет заключить, что большая часть публикаций посвящена проблеме коррупции, которая в современных российских реалиях имеет политическое звучание. Как и в 1990-е годы, она является результатом взаимодействия формальных и неформальных институтов (Бляхер, Пегин, 2012: 90).

Повестка рассмотренных интернет-проектов кардинально отличается от повестки традиционных СМИ и в особенности телевидения, где в новостных выпусках и документальных фильмах предпочтение отдается уже раскрытым правоохранителями преступлениям. Это может быть связано с цензурными ограничениями, о которых в своих интервью нередко рассказывают уволившиеся с федеральных телеканалов журналисты.

Расследования в интернет-проектах нового типа отличаются использованием большего объема данных и более глубокой проработкой проблемы, чем в традиционных СМИ. Активно используются современные методы интернетрасследований из арсенала известного британского проекта Bellingcat. Учитывая тренд на возрастающую популярность видеоконтента и мультимедийных форматов (Качкаева, 2010: 6), почти все расследовательские проекты к 2020 г. создали свои каналы в YouTube и обязательно выпускают хотя бы краткую видеоверсию расследования.

Многие расследователи сегодня регистрируются как некоммерческие организации по американскому образцу и существуют за счет пожертвований аудитории и спонсоров. Это позволяет им быть независимыми от государства и рекламодателя в формировании своей редакционной политики.

\section{СПИСОК ЛИТЕРАТУРЫ}

Анин Р., Махровская А., Шмагун О. «Номиналы» закупок [Электронный pecypc] URL: https://www.istories.media/investigations/2020/04/26/nominali-zakupok-/ (дата обращения: 21.05.2020).

Бляхер Л.Е., Пегин Н.А. (2012) Коррупция как политическая проблема: кто, как и зачем сражается с коррупцией в России // Полития. №4 (67). С. 89-103.

Болецкая К. Бывший главный редактор «Дождя» запускает новое медиа. 24.07.2018. [Электронный ресурc] URL: https://www.vedomosti.ru/technology/articles/2018/07/24/776415-redaktor-dozhdya?ref=vc.ru (дата обращения: 06.05.2020). 
Качкаева А.Г.(2010) Журналистика и конвергенция: почему и как традиционные СМИ превращаются в мультимедийные. М.: Фокус-медиа. 200 с.

Лукьянова Ю., Рубин М., Жолобова М., Баданин Р. ЗАО партия. 1.03.2019. [Электронный ресурc] URL: https://www.proekt.media/investigation/ldpr-business/ (дата обращения: 06.05.2020).

Забиранко Валерия Игоревна - магистрант I курса направления «Журналистика» Московского гуманитарного университета. Научный руководитель: А.Ю. Гарбузняк - кандидат филологических наук, доцент кафедры журналистики Московского гуманитарного университета. Адрес: 111395, Москва, ул. Юности, д. 5. Тел.: 8 (499) 374-60-91. Эл. адрес: zabirankovaleri@yandex.ru

Zabiranko Valeria Igorevna is a first-year Master's student in Journalism at Moscow University for the Humanities. Scientific supervisor: A. Y. Garbuznyak - Candidate of Philological Sciences, Associate Professor of the Department of Journalism of the Moscow University for the Humanities. Address: 5, Yunosti str., Moscow, 111395. Tel.: 8 (499) 374-60-91. E-mail: zabirankovaleri@yandex.ru

\section{Для цитирования:}

Забиранко В.И. Политические расследования в интернет-проектах нового типа // Научные труды Московского гуманитарного университета. 2020. №6. C. 124-127. DOI: https:// www.doi.org/10.17805/trudy.2020.6.22 